\title{
ПЯТЬ РОЖДЕНИЙ ЛИЧНОСТИ: СТУПЕНИ ПЕРСОНОГЕНЕЗА В АВТОБИОГРАФИЧЕСКОМ ТРАКТАТЕ М.М. ЗОЩЕНКО «ПЕРЕД ВОСХОДОМ СОЛНЦА»
}

\begin{abstract}
М.А. ЩУКИНА
${ }^{a}$ Санкт-Петербургский государственный институт психологии и социальной работы, 199178, Россия, Санкт-Петербуре, 12-я линия Васильевского острова, д. $13 \mathrm{~A}$

\section{Резюме}

Обсуждается актуальная для современной психологии концепция множественного рождения личности, где акт персонального рождения амплифицируется и разворачивается в масштабе всего жизненного пути, преодолевая замкнутость личностного становления в детско-юношеском периоде. Предлагается рассматривать персоногенез как систему пяти качественно своеобразных рождений личности. «Нулевое рождение» - создание личности как ожидаемой социальной модели и соответствующего определенному хронотопу социального проекта микро- и макроокружения будущего ребенка. «Первое рождение» связано с новообразованиями самосознания («Я» и «Я сам») и изменением в мотивационной сфере: принятием ребенком социальных норм и ценностей как мотивов своего поведения. «Второе рождение» приурочено к подростковому возрасту и проявляется в развитии общей субъектности личности с новообразованием способностей к самоопределению, самоуправлению, осознанному выбору ценностных ориентиров. Показано становление личности подростка за счет процессов самопознания, самоутверждения и саморегуляции в индивидуальном и групповом поступке. «Третье рождение», пролонгированно разворачивающееся в период взрослости, связано с развитием зрелости личности, проявляющейся в принятии ответственной жизненной позиции, самостоятельном и сознательном построении жизненного пути. Движущими силами третьего рождения обозначаются активность, рефлексивность и действенное усилие личности, направленные на саморазвитие и жизнетворчество. «Четвертое рождение» относится к последней фазе жизни человека или периоду после его смерти и понимается как воплощенная личностная представленность в значимом другом - персональный вклад в личностное пространство другого человека. Этапы развития личности иллюстрируются феноменологическим материалом автобиографического литературно-психологического трактата М.М. Зощенко «Перед восходом солнца».
\end{abstract}

Ключевые слова: личность, персоногенез, рождение, развитие, саморазвитие, зрелость личности, потребность быть личностью, персонализация, М.М. Зощенко, «Перед восходом солнцца . 
Я не знаю, где я родился. Я нигде не родился. Я вообще не родился. Я не я. Я не не. Не я не. Не, не, не. Я не родился в таком-то году. Ю.К. Олеша

«Перед восходом солнца». В психологическом сообществе Михаил Михайлович Зощенко почитаем не столько как автор блистательных сатирических рассказов и трагической «Голубой книги», но, прежде всего, как создатель необычного науино-литературного трактата «Перед восходом солниа» (Зощенко, 2006). Его самобытность кроется в выходе текста за рамки традиционного самоописания средствами литературы в область психологического анализа средствами науки.

Использованный писателем метод интерпретации биографического содержания не сводится к завуалированному под учение И.П. Павлова психоанализу, как полагает А.А. Пузырей (2005). На автобиографическом материале М.M. Зощенко сделал смелую для времени создания книги (1942-1943) попытку дать объяснение истории личности сразу на двух уровнях: психологическом (средствами психоанализа) и психофизиологическом (средствами условно-рефлекторной теории). Поэтому значимость предложенных им идей и трактовок не ограничивается стремлением прикрыть запрещенные к употреблению психоаналитические положения, а превращается в попытку преодолеть разорванность психологиеского и психофизиологиеского объяснений поведения и развития человека.

Писатель привлекает психоаналитические методы анализа сновидений, ранних детских воспоминаний, свободных ассоциаций и психосоматических реакций для поиска корней, причин человеческих страданий, но одновременно пытается выявить психофизиологический механизм формирования этих корней. Он не останавливается на том, чтобы найти травмирующие события раннего детства, констатировать их наличие и влияние на самочувствие взрослого человека, но пробует понять, каким образом эти травматические события закрепились в психике и продолжают влиять на поведение. Именно для решения данной задачи автор обращается к условно-рефлекторной теории, вскрывая нервные связи, сформировавшиеся и закрепившиеся за счет сочетанного повторения травмирующих стимулов (в контексте жизни автора это отбирающая рука, скальпель хирурга, гром и пр.) и приятных либо нейтральных объектов (грудь матери, мать, вода и пр.), которые в результате подобного сочетания стали восприниматься как потенциально опасные, а затем, претерпев генерализацию, распространили негативную аффективную окраску на весь класс подобных объектов (например, на всех женщин). Будучи литератором, не обремененным обязательствами научной корпорации, M.М. Зощенко находился над схваткой гуманитариев и естественников, пробуя на примере биографического самопознания раскрыть целостный механизм, определяющий поведение и переживание, где физиологическое и психологическое представляются только разными планами объяснения, требующими 
объединения в единую систему для обеспечения понимания целостной личности, поведения, жизни реального человека.

В то же время нельзя признать, что описанный М.М. Зощенко жизненный путь представлен в полноте спонтанности и самораскрытия. Те эпизоды жизни, которые он представляет читателю, есть избранные, даже специально подобранные фрагменты. Как всякий нарратив, автобиографический текст писателя являет не столько факты персоногенеза, сколько попытку его реконструкции и осмысления, выполненную для подтверждения верности «теории-о-себе». Однако неподдельная эмоциональность и семантическая многоплановость автобиографических новелл «Перед восходом солнца» заставляет все новые поколения психологов относиться к изложенным фрагментам как к живому материалу для поисков, интерпретаций и разгадок сегодняшними методами психологии с позиции актуальных теоретических идей современности. При таком взгляде оказывается, что в них заложены не только указанные автором смыслы, но и непредвиденные им темы для размышления, неожиданные темы психологического дискурса. Как выдающийся художник, М.М. Зощенко в оставленных им «вспышках памяти» предоставил ценнейший материал, который не только подтверждает современные ему научные находки, но и зачастую предвосхищает идеи, к которым психологическая наука подошла позднее. Так, в эпоху, когда психоанализ и бихевиоризм ожесточенно спорили о верности предлагаемых ими решений, М.М. Зощенко задолго до когнитивной революции 1950-х гг. привлекал внимание к потенциалу человеческого разума, который, по его мнению, есть сила, способная победить страдание: «Разум побеждает страх. Разум находит пути к счастью. Разум создает науку - науку достойной и справедливой человеческой жизни» (Зощенко, 2006, с. 615). Это настойчивый рефрен всего текста, резонирующий с идеями современной когнитивной терапии.

В данной статье ставится цель - показать на материале нарратива жизненного пути М.М. Зощенко актуальную для современного персонологического дискурса идею множественного рождения лииности. Ее содержание состоит в том, что личность развивается перманентно на протяжении всей жизни человека, не останавливаясь на пороге юности и проходя при этом несколько принципиальных точек качественного преобразования, которые в психологии принято называть «рождениями личности».

Предтечей данных идей в психологии стало положение философской антропологии и әкзистенциализма о жизни человека как борьбе за жизнь против смерти, за рождение против умирания (М.М. Бахтин, М.К. Мамардашвили, С.Л. Рубинштейн, Ж.-П. Сартр, И.Т. Фролов, Э. Фромм, М. Фуко, М. Хайдеггер и др.). Данная позиция строится на убеждении, что сущностно человек не рождается окончательно во время биологического акта рождения, а может не родиться и в течение всей жизни. Быть живым означает жить сознательно, постигая культуру и порождая ее, удаляясь все дальше от животного способа жизни. Быть неживым (или полуживым, спящим) - существовать подобно животному, руководствуясь биологическими инстинктами и социально выработанными автоматизмами. Жизнь понимается как рождение 
самого себя как человека - непрекращающийся процесс и постоянно возобновляемая задача. «Это значит, что человек - в качестве такового - должен снова и снова себя устанавливать и возобновлять, вновь и вновь рождаться заново, проходя через точки радикальной трансформации, метаморфозы... Человек - это существо, которое в качестве такового всегда заново, то есть "из ничего" и, по сути дела, всегда впервые рождается» (Пузырей, 2005, c. 462). Такой подход предписывает взгляд на человека не как на данность, а как на потенциальность, человека в процессе, в движении, в саморазвитии и постоянном рождении как борьбе за жизнь-творчество против жизни-автоматизма. «Личность рождается при решении экзистенциальной задачи освоения и овладения сложностью собственного бытия. В культуре многих народов называют человека, не испытавшего второго рождения, "однажды родившимся”. Именно в решении экзистенциальной задачи происходит, в отличие от созревания индивида, длинная вереница рождений личности или "человека в человеке"» (Зинченко, 1998, с. 10).

В психологии идея множественного рождения личности выросла из предложенной А.Н. Леонтьевым метафорь о двух рождениях личности. Личность «рождается дважды: первый раз - когда у ребенка проявляется в явных формах полимотивированность и соподчиненность его действий... второй раз когда возникает его сознательная личность» (Леонтьев, 1975, с. 211). Основанная на трезвом психологизме и в то же время обладающая мощной поэтической силой, метафора оказалась востребованной, когда отечественные психологи подошли к границе юношества и взрослости с вопросом, что происходит с личностью за этой границей. Накопленный за последние десятилетия материал эмпирических исследований, расширившаяся практика психологического консультирования и формирование в отечественной психологии новых теоретических подходов (неодеятельностного, субъектного, акмеологического, персонологического и др.) привели к утверждению положения о множественном рождении лииности, согласно которому акт рождения личности амплифицируется, преодолевая замкнутость личностного становления в детско-юношеском периоде.

В пределе личность рождается всякий раз, когда совершает ответственный и самостоятельный поступок (В.В. Петухов и В.В. Столин), когда решает экзистенциальные задачи жизни (В.П. Зинченко), когда отстаивает себя (А.Г. Асмолов), когда «на каждом повороте жизненного пути ему (человеку) нужно от чего-то освобождаться, что-то утверждать в себе» (Там же, с. 216). Однако на линии персоногенеза можно указать только несколько наиболее принципиально различающихся по своему содержанию и психическому механизму изменений личности, которые можно в полном смысле назвать ее рождениями. В разрабатываемой нами модели ступеней персоногенеза выделено пять рождений личности, где: «нулевое рождение»1 - создание личности как ожидаемой социальной сущности окружением будущего ребенка; «первое

1 Данный порядковый номер использован, чтобы не менять устоявшейся в психологии нумерации рождений личности. 
рождение» связано с новообразованиями самосознания «Я» и «Я сам» и принятием ребенком социальных норм, правил и ценностей как мотивов своего поведения; «второе рождение» проявляется в развитии обшей субъектности личности в регуляции поведения; «третье рождение» - в становлении зрелости как центрального новообразования личности взрослого человека; «четвертое рождение» - в выявлении личности как вклада в персональном пространстве других людей. Возвращаясь к цели статьи, раскроем и проиллюстрируем на материале жизнеописания М.М. Зощенко своеобразие каждого из рождений личности.

«Нулевое рождение» состоит в появлении личности как сверхчувственного социального качества в младенческом возрасте или даже на доиндивидном этапе «жизни» человека. Речь идет о замысле, предпосылке, предчувствии, мечте о личности, которая рождается социальной средой как виртуальная модель личности. Социальная макросреда в определенном историко-культурном контексте ожидает «героя нашего времени», личность, обладаюшую востребованными в определенном хронотопе качествами: мистичную, романтичную, фанатичную, трудолюбивую, предприимчивую, конкурентноспособную, принципиальную, лояльную и пр. Социальная микросреда в лице родителей и родственников конструирует личностный портрет будущего ребенка: он будет добрым, смелым, веселым, умным, хорошим врачом, спортсменом, знаменитым пианистом, матерью моих внуков, опорой старости, наследником дел и пр.

Ребенка еще может не быть телесно, но он уже существует как социальный проект. На него возлагают надежды, обязательства, права, играют с ним в коммуникативные игры, т.е. вступают в социальные отношения так же, как если бы он уже был. От ребенка ждут, каким он должен быть, он уже есть как потенция определенного содержания, которое в дальнейшем реализуется в процессе воспитания и образования посредством трансляции социальными институтами общественных и семейных требований, моральных максим, идеалов, норм, правил, табу, эталонов и примеров для подражания. Например, анализируя свои детские воспоминания, М.М. Зощенко констатирует ту горестную роль, которую сыграли в формировании его эмоциональных комплексов слова-установки матери: «- у тебя закрытое сердце / - Значит, я буду такой же, как дедушка?... / - Да, наверное, и ты будешь такой же. Это большое несчастье никого не любить» (Зощенко, 2006, с. 462); «Ты трудный ребенок. Я не верю, что ты будешь счастливый» (Там же, с. 461). Такого рода когнитивные единицы начинают работать как строительный материал для становящейся личности ребенка задолго до ее «первого рождения». Как справедливо замечает писатель, «первые встречи с вещами, первое знакомство с окружающим миром состоялось не в три и не в четыре года, а раньше, на рассвете жизни, перед восходом солнца» (Там же, с. 484).

«Первое рождение» характеризуется двумя основными новообразованиями личности. Первое из них происходит, как традиционно считается в отече- 
ственной психологии, в возрасте около трех лет² и связано с тем, что ребенок «ощущает себя как некую автономную единицу» (Леонтьев, 2013), что находит выражение в двух главных приобретениях самосознания: $\boldsymbol{A}$ и $\boldsymbol{A}$ сам. Л.И. Божович так описывала этот процесс: «Происходит переход ребенка от существа, уже ставшего субъектом (т.е. сделавшего первый шаг на пути к внутренней свободе), к существу, осознающему себя как субъекта, иначе говоря, к возникновению того системного новообразования, которое принято связывать с появлением слова “я"» (Божович, 2008, с. 329); «Рождаемая этим новообразованием потребность действовать самому... выражается в постоянном и настойчивом требовании ребенка - “Я сам"» (Там же, с. 331). До этого момента самопознание ребенка «продолжает оставаться для самого ребенка (субъективно) познанием как бы внешнего ему самому предмета» (Там же, с. 229). Ребенок, как и взрослый, в процессе самопознания выступает субъектом познания и его же объектом. Однако для взрослого человека эта субъект-объектная структура выступает в свернутой форме, тогда как у ребенка она представлена буквально, ибо он относится к изучаемым частям своего тела как к посторонним, как к игрушкам или частям тел взрослых. Буквальное отношение ребенка к себе как к объекту, тождественному другим объектам внешнего мира, позднее приобретает интериоризированную форму в виде «образа-объекта-себя» в мире внутреннем.

В биографических новеллах М.М. Зощенко блестяще демонстрирует этот переворот в жизни личности. В рассказе «Туфельки едут» описано состояние «до» первого рождения личности - отсутствие осознанности Я, четкой границы Я, вместо которой существует ощущение слитности с миром, нерасчлененность Я и Иного. Мои ножки - это такой же предмет мира, как любой другой; они не подчинены, не подвластны мне, а едут на извозчике сами по себе. Я не появилось еще как онтологическая, действенная единица, оно разлито в среде роста, где зреет, как в питательном субстрате. Контрастная картина мироощущения ребенка «после» рождения личности дана в рассказе с симптоматичным названием «Сам», где в словах и поведении героя показаны центральные новообразования первого рождения личности: «Сам буду кушать. Глотаю кашу. Горячо. Реву. Со злостью колочу ложкой по блюдщу. Брызги каши летят в лицо, в глаза. Невероятный крик. Это я кричу». Это неудержимая интенция проявить, воплотить в действии активность этого еще неведомого Я и осознание своего Я как действенной причины изменения в мире: Я могу сделать брызги каши, Я могу кричать, это Я могу создать невероятный крик.

Другое новообразование первого рождения личности - принятие ребенком социальных норм, правил и ценностей как мотивов своего поведения. «Внешне это проявляется, например, в способности ребенка "не взять" понравившийся ему предмет только потому, что "мама запретила его трогать”. Даже когда его никто не видит, ребенок может ходить вокруг этого предмета, но трогать

${ }^{2}$ Наблюдения современных психологов, воспитателей и родителей показывают, что в настоящее время происходит постепенное смещение возрастньх границ проявления данного новообразования к двум годам. 
не будет. Значит, социальная норма, выступавшая внешним регулятором поведения ребенка (раньше ребенок не трогал предмет только в присутствии мамы или другого взрослого), теперь становится внутренней формой регуляции. Таким образом, у данного ребенка начался процесс иерархизации мотивов, при этом все более и более значимым для него становится выполнение им социальной нормы» (Соколова, 2005, с. 258). В тексте М.М. Зощенко эта веха в развитии личности показана в рассказе «Я больше не буду», где герой еще не в полной мере соблюдает родительский запрет есть виноград, но уже понимает: то, что он делает, это «нехорошо». Мы наблюдаем самый момент рождения, когда личность как будто проклевывается и ребенок начинает делать это «нехорошо» вполсилы, «вполпорции»: он не съедает ягоды, а только надкусывает их. Родительское подкрепление ошибочности данной стратегии в виде немедленного наказания помогает личности окончательно родиться, ребенок дает первый социальный обет: «Я больше не буду!»

«второе рождение» в отечественной психологии принято связывать с подростковым возрастом. Однако его точные границы более размыты, чем первого, а состоятельность является скорее потенциальной, чем гарантированной. В истории личности только первое рождение является предустановленным, да и то при отсутствии у ребенка неврологических аномалий и при наличии минимального режима благоприятствования социальной среды. Социальный индивид, которым ребенок становится после первого рождения личности, как отмечали В.В. Петухов и В.В. Столин (Петухов, 1998), может так и не стать личностью в подростковом периоде, если не примет на себя груз самостоятельности и ответственности, соответствующий личностному способу существования. Второе и особенно третье рождения личности факультативны (в терминах Д.А. Леонтьева), т.е. не предзаданы и не гарантированы человеку, так как на первый план в их осуществлении выходит фактор осознанного персонального усилия. Рождение Я перестает быть радостью откровения ребенка, a «происходит в напряженной внутренней работе, когда человек как бы постоянно решает задачу, “чему во мне быть” (Леонтьев, 1976), т.е. развитие начинает переходить в саморазвитие.

Готовность совершить личностное усилие - центральный компонент движущей силы саморазвития и одновременно показатель уровня развития личности, ибо, согласно В.М. Розину, личность есть прежде всего «самостоятельное поведение и усилия, направленные на построение самого себя, своей жизни» (Розин, 2009, с. 92). Д.А. Леонтьев использует понятия «культура усилия» и «экзистенциальный тонус», чтобы продемонстрировать меру затрат, необходимую для личностного развития по пути взращивания человеческой сущности: «Становление человека - это самостановление, активный процесс, связанный не столько с вызреванием чего-то заложенного, сколько с работой. Не столько с работой над собой, сколько с работой над чемто в мире, что имеет смысл. Нет такого эскалатора, на который можно было бы встать и он будет сам возносить вас к вершинам личностного развития» (Леонтьев, 2007). 
В биографических новеллах М.М. Зощенко можно выделить основные линии персоногенеза в подростковом возрасте. Прежде всего, это развитие самосознания как важнейшего инструмента и в то же время поля активной трансформации подростка. В новелле «Муза» показано, как обостряется у младшего подростка стремление сравнить себя со значимьми Другими и найти свое место на различных социальных шкалах, тем самым отрегулировав свою Я-концепцию и самооценку. В этом же рассказе развернут еще один механизм развития личности подростка - примеривание новых социальных ролей (жених и невеста), которые находятся в активно исследуемой подростками зоне взрослости. «Подросток, - как отмечала Л.И. Божович, - в отличие от младшего школьника, обращен в будущее... Невозможность практически изменить свой образ жизни порождает мечты... В них всегда имеет место то или иное “моделирование" своего будущего и себя в этом будущем» (Божович, 2008, с. 352).

В ходе осознания, распознания своего вновь рождаюшегося Я подросток сталкивается с еще одной возрастной задачей - науииться управлять своим новым Я, которое еще так неясно и непривычно. «Когда говорят: подросток открывает свой внутренний мир с его возможност ями, устанавливая его относительную независимость от внешней деятельности, то, с точки зрения того, что нам известно о культурном развитии ребенка, это может быть обозначено как овладение внутренним миром» (Выготский, 1983, с. 327-328). В новелле «Снова неприятности» М.М. Зощенко раскрывает подростковый опыт овладения собой через приобретение умения ходить с закрытыми глазами. Писатель замечает абсурдность подобной затеи с позиции взрослого человека (матери, учителя), которому ее смысл даже объяснять бесполезно - не поймет. Но во внутренней логике подростка важно не забавное умение как таковое, а принципиально новая психическая процедура, новый осваиваемый механизм его приобретения. Подросток «учится властвовать собою»: ставить себе задачу, определять условия успешности ее осуществления, находить внутренние ресурсы и средовые возможности для ее осуществления, преодолевать трудности и ограничения при ее решении. «Второе рождение личности - это интенциональная, смысловая эмансипация; личность становится способной не только выполнять самостоятельно какие-то действия, но и самостоятельно относиться к ним, самостоятельно решать вопросы о том, что нужно, что важно, а что не важно» (Леонтьев, 2013, с. 76-77).

Важнейшей задачей подростка является становление способности к самоутверждению - способности отстоять перед социумом содержание своего нового Я: избранные ценности, взгляды, принципы, вкусы. В рассказах о подростничестве М.М. Зощенко демонстрирует контрастное поведение «до и после» становления данной способности: еще не перешедшего свой Рубикон подростка и беспомощно безропотного перед мнением учителя (новелла «Хлорофилл»), несмотря на полное осознание своей правоты, и подростка, который подвластными ему средствами, могущими показаться смешными и нелепыми, добивается своей цели - утверждает важное для себя право на уважение со стороны учителя чувства собственного достоинства (новелла 
«Учитель истории»). Писатель подчеркивает, какой смелости, внутреннего напряжения, переходящего во внешнюю дрожь, стоит подростку такое завоевание, находящееся на грани социального фола, но награда велика - слезы радости от состоявшегося рождения нового, сильного Я.

Наконец, в произведении М.М. Зощенко можно обнаружить еще одну важнейшую черту второго рождения личности - стремление подростков объединиться в группу для совместной реализации значимьх ценностей в групповом nоступке. Чаще в психологии принято обсуждать данную особенность возраста для анализа девиантного поведения. Но в новелле М.М. Зощенко «Студент со стеком» приведен пример иного рода, где раскрывается опыт действенной защиты социально одобряемых и при этом личностно значимых для каждого из друзей писателя ценностей. Они протестуют против цинизма и жестокости студента-ловеласа, обманувшего юную дачницу. Протестуют не вздохами и слезами, как взрослые респектабельные соседи, но собираются в группу, в коллективное Я, чтобы преодолеть телесную незрелость, чтобы хватило сил защитить свои идеалы в сражении с ненавистными чертами окружающего мира, воплотившимися в фигуре эгоиста-соблазнителя.

«Третье рождение», центральным новообразованием которого является зрелость личности, детерминировано комплексом персональных факторов с определяющим воздействием процессов самопознания, самодетерминации и саморазвития.

Приведем примеры содержательной разработки положения о третьем рождении личности в отечественных персонологических концепциях. Л.И. Анцыферова выделяет три уровня развития личности, высший из которых может быть понят как результат третьего рождения. На нем личность становится субьектом жизненного пути и определяется степенью своей индивидуальности - «свободы выявлять, переживать и свойственными действиями разрешать назревшие противоречия развития общества» (Анцыферова, 2000, с. 212). Н.С. Пряжников и Е.Ю. Пряжникова при разработке проблем психологии труда предлагают ввести понятие третьего рождения личности для обозначения гражданской зрелости и способности согласовывать своих мотивы с общественными и даже общечеловеческими. Они образуются, по мнению авторов, именно в профессиональной деятельности, когда уже повзрослевший человек максимально реализует свой потенциал и когда для него становится особенно важным и полезным размышлять о том, ради чего он не только трудится, но и вообще живет, а также о том, как профессиональная деятельность позволяет ему передать все лучшее, что у него есть, другим людям (Пряжников, Пряжникова, 2009). Е.Л. Доценко называет задачей также выделяемого им третьего рождения личности осмысленное размещение человеком самого себя в системе общественных отношений с осознанием причин выбора своей жизненной позиции и с полной ответственностью за последствия своего выбора (Доценко, 2009, с. 71). Д.А. Леонтьев проводит идею третьего фактора, третьего измерения, «развития $3 \gg$, под которым автор понимает две альтернативные линии персоногенеза взрослого человека. Одна из них («развитие 3 А») связана с формированием 
«базовой личности» для определенного общества, конформистской личности (содержательно близкой «социальному индивиду» в терминах В.В. Петухова и В.В. Столина). В линии «развития 3 Б» «человек выступает как автономный субъект, как личность, решаюшая задачи выбора и самодетерминации собственной жизни. Цель развития человека в третьем измерении - собственный путь жизни, нахождение и построение собственной траектории» (Леонтьев, 2013, c. 78).

Третье рождение личности можно представить не как единомоментное событие, а как следование выбранному личностью способу самосозидания через самостоятельное вистраивание социальной средь развития (Б.Г. Ананьев) и вьюор определяюиих развитие видов деятельности (А.Г. Асмолов). Движуцими силами третьего рождения являются активность, рефлексивность и действенное усилие личности, направленнье на саморазвитие u жизнетвориество. Задача взрослого человека - «стать менеджером самого себя, создать собственный мир и траекторию жизни, способствовать становлению новых форм сообщительности» (Розин, 2016, с. 381). Осознание такой задачи проявляется в субъективном открытии возможности и долга руководить своим развитием и управлять своей жизнью. Для подростка актуализируется необходимость научиться управлять своим актуальным Я «здесь-и-сейчас», для взрослого эта задача поднимается на новый уровень сложности - управлять «Я в динамике» персоногенезом и выстраиванием жизненного пути. Ее решение становится экзаменом на личностную зрелость человека, которая проявляется в «способности вести себя независимо от непосредственно воздействующих на него обстоятельств (и даже вопреки им), руководствуясь при этом собственными, сознательно поставленными целями. Возникновение такой способности обуславливает активный, а не реактивный характер поведения человека и делает его не рабом обстоятельств, а хозяином и над ними, и над самим собой» (Божович, 2008, c. 322). Зрелая личность в состоянии сделать жизнь предметом преобразований, потому только она может быть в полной мере названа субъектом жизни. «Под зрелостью имеется в виду способность человека к пропорциональному жизненным задачам расходованию, продуктивному применению своих личностных возможностей и особенностей своего типа личности... Только зрелый человек способен своей волей определять и направлять ход событий и расстановку сил в своей жизни» (Абульханова-Славская, 1991, с. 285).

Третье рождение не имеет четких возрастных границ: оно совершается в жизни человека раньше или позже, а может не произойти вовсе. «Зрелость приходит не с возрастом, а с принятием ответственности. При условии, когда человек научится реализовывать жизненные замыслы, перспективы, когда от самоопределения перейдет к самореализации, только тогда о нем можно сказать, что он является зрелой личностью» (Ильин, 2012, с. 38). При этом К.А. Абульханова-Славская обращает внимание на то, что у большинства людей наблюдается несовпадение реальных и идеальных качеств, являющееся показателем противоречия между «Я-идеальным» и «Я-реальным». Однако, даже осознавая идеал, многие люди не стремятся себя изменить. А ведь в этом, 
по мнению исследователя, и заключается важнейшая потребность личности потребность в развитии и саморазвитии. Развитие, подчеркивает К.А. Абульханова-Славская, это «не только уровень и качество психических процессов, даже не совершенство отдельных личностных свойств, способностей, но конструктивный творческий характер способа жизни личности» (Абульханова-Славская, 1991, с. 285). Выбор и реализация стратегии развития зависят от самой личности, определяются ее системой ориентаций, жизненной позицией и степенью зрелости.

Зрелость личности в трактате М.М. Зощенко представлена в двух значениях: 1) как нормативная траектория возрастного развития: от незрелости юношества к зрелости взрослости; 2) как альтернатива проживания взрослости: деградация или борьба за совершенствование.

Раскрывая «зрелость» в первом значении, автор противопоставляет образ незрелого гимназиста, пасующего перед мелкой обидой от полученной «двойки», отказывающегося от жизни из-за раненого самолюбия (новелла «Пытка»), и молодого, но уже состоявшегося писателя, который твердо идет по выбранному пути (новелла «Опять чепуха»): «Я не огорчаюсь. Я знаю, что я прав» (Зощенко, 2006, с. 419). Между этими событиями была война и революция, отравление газами и отклоненная эмиграция, мучительные поиски себя, десятки перепробованных профессиональных и социальных ролей (студент, офицер, сапожник, птицевод, адъютант и т.д.). Писательство становится для М.М. Зощенко не просто очередной профессиональной нишей, а выстраданным призванием с четким пониманием своего предназначения в жизни и литературе, с точной оценкой своих возможностей и притязаний, с ясным ви́дением своих ценностей и принципов. Преодолев родовые пути третьего рождения, осознав цель и смысл своей дальнейшей жизни, он достигает личностной зрелости и решительно идет путем индивидуализации и творчества, и это соответствует определению А.Г. Асмолова: «Быть личностью - это значит иметь активную жизненную позицию, о которой можно сказать: "На том стою и не могу иначе"» (Асмолов, 2001, с. 404).

О «зрелости» во втором значении новелла М.М. Зощенко «Встреча», которая раскрывает картину психологической трагедии личности, которая отказалась от усилий саморазвития, от возможности аккумулировать свои ресурсы для преодоления жизненных препятствий и неурядиц. Для писателя образ героя этого рассказа, как и еще целого ряда подобных повествований («Дом искусств», «Кафе “Двенадцать” и др.), выполняет функцию предупреждения и предостережения: каким я буду, если смирюсь, позволю себе плыть по течению, поддамся безмыслию и безволию. Такой образ - помощь в минуты отчаянья, когда представляется, что силы для жизненной борьбы на исходе.

На личном примере М.М. Зощенко доказывает, что взять развитие в свои руки - посильная задача. Предпринятое им самоисследование и самопреобразование, запечатленные в трактате «Перед восходом солнца», - опыт активации силы самосознания для овладения персоногенезом. Испытывая, по свидетельству современников, постоянные приступы тревоги и депрессиии (в том числе уже после того, как М.М. Зощенко казалось, что он нашел разгадку 
своих страданий), писатель даже создание текста трактата превращает в средство самопомощи, подтверждая идею Е.Е. Сапоговой (2011) об автобиографировании как процессе самодетерминации личности. «Юношеские мои годы были окрашены черной краской, меланхолия и тоска сжимали меня в своих объятиях. <..> Я захотел изменить свою несчастную судьбу. Я предпринял атаку против тех врагов, каких я обнаружил путем следственного розыска. <..> Я вышел победителем. Я стал иным после этой битвы» (Зошенко, 2006, c. 633).

«Четвертое рождение» мы связываем с идеей В.А. Петровского о стремлении «персонализироваться», «полагать себя в другом» как движущей силе развития личности: «Определяющая цель развития личности - быть значимъцм Әругим для значимого другого (других)» (Петровский, 1996, с. 260). Данное побуждение является важным детерминатором социального бытия всей жизни человека. Быть отраженным в другом, быть важным для другого, оказывать влияние на поступки другого - проявления действенной с младенческого возраста, пусть и не всегда сознаваемой, потребности быть личностью. Однако в финальной фазе жизни эта потребность обретает особое звучание.

В последний раз личность рождается после смерти организма в качестве виртуальной сущности во внутриличностном пространстве других людей («бытие в другом и для другого»). Личность продолжает существование в качестве вклада в других людей до тех пор, пока она востребована, необходима для живущих. Она остается наделенной разнообразными качествами, с ней вступают в отношения и в общение: ее могут обожать или ненавидеть, с ней могут советоваться в случае важных жизненных выборов, на нее могут ориентироваться как на эталон или антипод, у нее могут просить поддержки и прощения. Финальное рождение является не подвластным человеку в полной мере, но залогом, повышающим его вероятность, является то, насколько он еще при жизни нужен и значим для окружающих, насколько он сумел при жизни оставить свои личностные вклады в других людях: «Полагая себя как субъект, человек отражается в других людях, обретая в них свою идеальную представленность и продолженность» (Петровский, 1993, с. 6).

Потребность быть личностью и после смерти может рассматриваться в качестве основной движущей силы литературного творчества М.М. Зощенко в зрелые годы. Тема смерти и опасности небытия волновала писателя давно. Он описывает эпизод, когда решил посетить деревню, где ребенком проводил каждое лето с родителями. Он искал людей, которые были знакомы ему по детским воспоминаниям, и не нашел никого из них: они умерли и были забыты даже жителями деревни. Этот факт поразил литератора: «С грустью я шел по деревенской улице. Только улица и дома были те же. Обитатели были иные. Прежние пожили здесь, как гости, и ушли, исчезли, чтоб никогда сюда не вернуться. Они умерли. Мне показалось, что в тот день я понял, что такое жизнь, что такое смерть» (Зощенко, 2006, с. 501). Страх исчезнуть навсегда, превратиться из Я в ничто породил в писателе тягостное уныние и апатию. «Все показалось вздором, чушью в сравнении с той картиной короткой жизни, которую я увидел сегодня. Стоит ли думать, бороться, искать, защищаться? 
Стоит ли “по-хозяйски” располагаться в жизни, которая проходит так стремительно, с такой обидной, даже комичной быстротой?» (Там же, с. 501-502). После этого М.М. Зощенко начинает искать, как можно преодолеть эту неизбежную угрозу, как зацепиться в этом мире, остаться в памяти людей. И как человек искусства, он ищет средство спасения не в масштабе семьи, знакомых и друзей. Для него важно быть значимым в масштабе генерализованного читателя, быть, подобно А.С. Пушкину, «любезным народу» плодами своего творческого труда, потому свой мост в вечность он строит литературным творчеством.

Во время Великой Отечественной войны М.М. Зощенко чувствовал свою полную бесполезность, ибо не мог по состоянию здоровья, подорванного в боях Первой мировой войны, принять участие в новой битве. Он как никогда остро ощутил границу небытия, угрозу перестать быть не только в телесном, но и в личностном плане. Именно поэтому спешно, не откладывая «на потом», он берется за оформление рукописи «Перед восходом солнца», над которой работал в черновиках около десяти лет. Писатель стремится доказать людям, что он тоже в рядах сражающихся, что полезен, ибо является носителем уникального знания о том, как освободиться от пустой хандры, печали, огорчений, стать бодрым и счастливым. Подкрепляет писателя в важности подобной миссии опыт его предыдущих произведений, которые помогали людям изменять понимание жизни и самих себя. М.М. Зощенко вспоминает о полученном письме от приговоренного к высшей мере наказания преступника, зарубившего из мести семью своего соседа. «Находясь в камере, этот малограмотный человек читал книги, и среди них повстречался с моей книгой "Возврашенная молодость". Я не знаю, что понял этот человек, прочитав мою книгу, но одну идею он уразумел. Он понял, что человек может и должен руководить собой. Пораженный этой простой мыслью, преступник написал мне письмо о том, что если б он знал об этом - он не совершил бы своего преступления. Но он не знал, что можно управлять своими чувствами» (Там же, с. 636).

Передать свой опыт страдания, его преодоления, обретения гармонии и зрелости, чтобы заслужить признательность потомков и продлить свою личностную историю в их личностях, - это центральная мотивация создания книги «Перед восходом солнца». Судя по тому, что книга востребована до сих пор, финальное рождение личности М.М. Зощенко состоялось.

\section{Литература}

Абульханова-Славская, К. А. (1991). Стратегия жизни. М.: Мысль.

Анцыферова, Л. И. (2000). Психология формирования и развития личности. В кн. Л. В. Куликов (сост.), Психология лииности в трудах отечествениых психологов: Хрестоматия. СПб.: Питер.

Асмолов, А. Г. (2001). Психология лииности: Приниипы обиепсихологического анализа. М.: Смысл. Божович, Л. И. (2008). Личность и ее фориирование в детском возрасте. СПб.: Питер. 
Выготский, Л. С. (1983). Проблемы развития психики. В кн. Л. С. Выготский, Собрание сочинений (т. 3). М.: Педагогика.

Доценко, Е. Л. (2009). Психология лииности. Тюмень: Изд-во Тюменского государственного университета.

Зинченко, В. П. (1998). Психологиеская педагогика. Материалы к курсу лекиий. Часть I. Живое Знание. Самара: Изд-во Самарского государственного педагогического университета.

Зощенко, М. М. (2006). Деньги. Любовь. Неудаии. М.: Эксмо.

Ильин, Е. П. (2012). Психология взрослости. СПб.: Питер.

Леонтьев, А. Н. (1975). Деятельность. Сознание. Лииность. М.: Политиздат.

Леонтьев, А. Н. (1976, 1 сентября). Начало личности - поступок. Комсомольская правда. Режим доступа: http://www.anleontiev.smysl.ru/pervoist/3-49.htm

Леонтьев, Д. А. (2013). Личностное измерение человеческого развития. Вопросы психологии, 3, 67-80.

Леонтьев, Д. А. (2007) Человечность как проблема. В кн. Материалы науииой конференици «О природе иеловека» (VII Фроловские итения) 20 ноября 2007 г. Режим доступа: http://www.frolov-it.ru/mem7.html.

Петровский, В. А. (1993) Феномен субъектности в психологии лииности: дис. ... д-ра психол. наук.

Петровский, В. А. (1996). Личность в психологи: парадигма субъектности. Ростов н/Дону: Феникс.

Петухов, В. В. (1998). Понятие личности. Функциональные различия природы и культуры. Общее представление о развитии личности. В кн. В. В. Петухов (ред.), Общая психология. Сборник текстов (Вып. 2). М.: Изд-во Московского университета.

Пряжников, Н. С., Пряжникова, Е. Ю. (2009). Психология труда. М.: Академия.

Пузырей, А. А. (2005). Психология. Психотехника. Психагогика. М.: Смысл.

Розин, В. М. (2009). Конструирование себя и реальности как способ жизни новоевропейской личности и философа. Вопросы философии, 7, 91-106.

Розин, В. М. (2016). От взглядов Л.С. Выготского к современной концепщии развития. Психология. Журнал Высией иколь экономики, 2, 367-383.

Сапогова, Е. Е. (2011). Автобиографирование как процесс самодетерминации личности. Культурно-историческая психология, 2, 37-51.

Соколова, Е. Е. (2005). Общая психология (Т. 1). М.: Академия.

Ссылки на зарубежные источники см. в разделе References после англоязыиного блока.

Щукина Мария Алексеевна - заведующая кафедрой общей, возрастной и дифференциальной психологии, Санкт-Петербургский государственный институт психологии и социальной работы, доктор психологических наук.

Сфера научных интересов: психология развития и саморазвития личности, субъектность и зрелость личности, история и методология психологии.

Контакты: corr5@mail.ru 


\title{
Five Births of the Personality: Stage of Personogenesis in the Autobiographic Tracture M.M. Zoshchenko "Before the Sunrise"
}

\author{
M.A. Schukina ${ }^{\mathrm{a}}$ \\ ${ }^{a}$ St.Petersburg State Institute of Psychology and Social Work, 13 a 12th line Vasilevsky island, St.-Petersburg, \\ 199178, RussianFederation
}

\begin{abstract}
Abstracr
The article discusses topical for the contemporary psychology concept of multiple births of personality, and the act of personal birth amplifies and unfolds in the scope of the whole life path, transcending the closure of personal formation in pre-adolescent period. Personogenesis is viewed as a system of five qualitatively unique births of personality. "Zero birth" is a formation of personality as an expected social model and corresponding to the definite chronotope social project of micro- and macro-environment of a future child. The "first birth" is linked with the emergence of self-consciousness ("I" and "self") and the changes in the motivational sphere: acceptance by a child of social norms and values as motives of their behaviors. The "second birth" is dated to the adolescent period and is manifested in development of general subjectivity of personality with the emergence of abilities of self-determination, self-regulation, conscious choice of values. The personality of an adolescent is formed due to the processes of self-knowledge, selfaffirmation and self-regulation in individual and group deeds. The "third birth" is extensively unfolds in the period of adulthood and is linked with the maturation of personality, which manifests in acceptance of responsible life position, independent and conscious forming of one's life path. The driving forces of the third birth are activity, reflexivity and active effort of personality, which are focused on personal growth and creative life. The "forth birth" pertains to the last phase of person's life or period after their death and is understood as an embodied personal representation in a significant other - personal input into personal space of another person. These stages of personality development are illustrated by a phenomenological material of autobiographical literary-psychological work by M.M. Zoshchenko Before Sunrise.
\end{abstract}

Keywords: personality, personogenesis, birth, development, self-development, maturity of personality, the need to be a person, personalization, M.M. Zoshchenko "Before sunrise".

\section{References}

Abulkhanova-Slavskaya, K. A. (1991). Strategiya zhizni [Life strategy]. Moscow: Mysl. (in Russian) Antsyferova, L. I. (2000). Psihologija formirovanija i razvitija lichnosti [The psychology of formation and development of personality]. In L. V. Antsyferova (Ed.), Psihologija lichnosti o trudah otechestvennyh psihologov [The psychology of personality in works of Russian psychologists]: Saint Petersburg: Piter, 2000. (in Russian)

Asmolov, A. G. (2001). Psihologija lichnosti: Principy obshhepsihologicheskogo analiza [Personality Psychology: Principles of general psychological analysis]. Moscow: Smysl. (in Russian)

Bozhovich, L. I. (2008). Lichnost'i ee formirovanie v detskom vozraste [Personality and its development in childhood]. Saint Petersburg: Piter. (in Russian) 
Dotsenko, E. L. (2009). Psihologija lichnosti [Psychology of personality]. Tyumen: University of Tyumen. (in Russian)

Il'in, E. P. (2012). Psikhologiya vzroslosti [Psychology of adulthood]. Saint Petersburg: Piter. (in Russian)

Leontiev, A. N. (1975). Deyatelnost, soznanie, lichnost [Activity, consciousness, personality]. Moscow: Politizdat. (in Russian)

Leontiev, A. N. (1976, 1 September). Nachalo lichnosti - postupok. [The start of the personality is the deed]. Komsomol'skaja pravda. Retreieved from http://www.anleontiev.smysl.ru/ pervoist/349.htm (in Russian)

Leontiev, D. A. (2013). Lichnostnoe izmerenie chelovecheskogo razvitija [The personality dimension of human development]. Voprosy psikhologii, 3, 67-80. (in Russian)

Petrovsky, V. A. (1996). Lichnost o psikhologii: paradigma sub"ektionosti [The personality in psychology: The paradigm of subjectivity]. Rostov-on-Don: Feniks. (in Russian)

Petukhov, V. V. (1998). Ponjatie lichnosti. Funkcional'nye razlichija prirody i kul'tury. Obshhee predstavlenie o razvitii lichnosti [The concept of personality. Functional differences of the nature and culture. General notion of the personality development]. In V.V. Petuhkov (Ed.), Obshhaja psihologija [General psychology]. Collection of texts. Iss. 2: «Sub"ekt dejatel'nosti». Moscow: Moscow University Press. (in Russian)

Pryazhnikov, N. S., \& Pryazhnikova, E. Y. (2009). Psikhologiya truda [Industrial psychology]. Moscow:Akademiya. (in Russian)

Puzyrej, A. A. (2005). Psihologija. Psihotehnika. Psihagogika [Psychology. Psychotechnics. Psychogogics]. Moscow: Smysl. (in Russian)

Rozin, V. M. (2009). Konstruirovanie sebja i real'nosti kak sposob zhizni novoevropejskoj lichnosti i filosofa [Creation of itself and the reality as the way of the life of the new european person and the philosopher]. Voprosy Filosofii, 7, 91-106. (in Russian)

Rozin, V. M. (2016). Views to the contemporary conception of development]. Psychology. Joumal of the Higher School of Economics, 13(2), 367-383. (in Russian)

Sapogova, E. E. (2011). Avtobiografirovanie kak process samodeterminacii lichnosti [Autobiographic Activities as the Process of Personal Self-Determination]. Cultural-Historical Psychology, 2, 37-51. (in Russian)

Sokolova, E. E. (2005). Obshhaja psihologija [General psychology]. Vol. 1. Moscow: Akademiya. (in Russian)

Vygotskij, L. S. (1983). Problemy razvitija psihiki [Problems of mind development]. In L. S. Vygotskii, Sobranie sochinenij [The collected works]. (Vol. 3). Moscow: Pedagogika. (in Russian)

Zinchenko, V. P. (1998). Psikhologicheskaya pedagogika. Materialy k kursu lektsiy [Psychological education: materials for the lecture course]. Samara: Izd-vo Samarskogo gosudarstvennogo pedagogicheskogo universiteta. (in Russian)

Zoshchenko, M. M. (2006). Den'gi. Ljubov'. Neudachi. [Money. Love. Failures]. Moscow: Eksmo. (in Russian)

Mariia A. Schukina - head, department of general, developmental and differential psychology, St. Petersburg State Institute of Psychology and Social Work, D.Sc.

Research area: psychology of development and self-development of personality, activity and maturity of personality, history and methodology of psychology.

E-mail: corr5@mail.ru 